\title{
Linguistic and Communicative Aspect of Business Education in A Modern Economic University
}

\author{
Larysa Bondarchuk ${ }^{1}$, Nataliia Boiko $^{1}$, Tamara Podgurska ${ }^{1}$, Viktoria Tovstenko ${ }^{1}$, and Nina Kryvych $^{1}$ \\ ${ }^{1}$ Kyiv National Economic University named after Vadym Hetman, Kyiv, Ukraine
}

\begin{abstract}
The paper considers specific language and communication projects conducted at the Kyiv National Economic University named after Vadym Hetman, which promote the humanization of business education, provide practical implementation of knowledge and skills of students of an economic university, increase professional, linguistic and cultural competencies of future professionals. Moreover, humanitarian projects are based on the interdisciplinary and cross-cultural foundations, that enriches the process of studying business disciplines, promotes intercultural ties, forms patriotic, civilizational and universal values.
\end{abstract}

\section{Introduction}

The task of a modern university is to educate a competent person who not only has knowledge and high moral qualities, but is able to act independently, in a non-standard way and creatively in various life situations, applying their knowledge and experience, taking responsibility for their own activities.

The Kyiv National Economic University named after Vadym Hetman has been among the leaders in training highly qualified specialists in the fields of economics, public and corporate governance, and economic law for many years. The University is actively working to provide the public demand for professional training of graduates, constantly monitoring the labor market, studying the requirements of employers for the specialists' qualifications and starting new educational programs, including implementation of joint educational programs with foreign higher education institutions and introduction of educational franchising. The University actively implements current programs of professional training, retraining, advanced training; it improves the methodological, organizational, legal and financial bases to provide the academic mobility of students, graduate students and teachers, as well as to develop double and joint graduation programs. The modernization of the educational process by updating the content of educational programs, their educational and methodological support, implementation of creative educational programs and innovative authors' courses, development and use of distance learning courses, video lecture courses for leading university teachers and teachers from partner foreign higher educational institutions is constantly carried out. The expansion of the range of selective courses, the improvement of the mechanism and procedure for their selection, the introduction into the educational process of active, interactive, game, problematic and other modern innovative technologies, forms and methods for preparing students for fuller development of their personal potentials are implemented. Leading scientists, specialists of various organizations and institutions, practitioners are actively involved in the educational process.

Business education has to consistently form students' economic thinking and consciousness, to educate reasonable needs, to develop abilities in a certain type of activity, to cultivate a careful attitude to the nature, to equip specialists with theoretical knowledge and practical skills in the culture of work, to form the needs of economic analysis, the vision of perspective, to learn to master the basics of the scientific organization of labor in market relations, to form in students the desire and need to improve the results of their work in educational and socially useful activities on a daily basis.

The great opportunities in ensuring a high level of business education are provided by the application of the method of educational projects. Finally, the ability to create, implement or participate in the projects is a significant vital competence of a person, the basics of which can be optimally formed and developed under the conditions of personal training at an educational institution.

\subsection{Project method}

The project work is actively used at the Kyiv National Economic University named after Vadym Hetman for studying various disciplines. In the course of project activities, students learn to: plan their work, predicting its results in advance; analyze and compare facts; argue their own judgments; make a decision; establish social contacts, use various sources of information; distribute responsibilities, interact; create a real "end product";

* Corresponding author: larysa.bondarczuk@ukr.net 
present the results to the audience; evaluate their activities and the activities of partners. The project activities are characterized by joint work of a teacher and a student with equal status of both parties.

The project activities are aimed at solving the following psychological-pedagogical and organizational-pedagogical tasks: the development of cognitive interests, intellectual and creative abilities of students; socialization of students, development of key competencies communicative, cooperative, informational, etc.; the formation of active life position; creating an atmosphere of cooperation.

A. Tsymbalaru emphasizes on the three directions of interpretation of the term "project" in the pedagogical science. "First, as a preliminary one, approximate text of the full document (draft program, etc.) is... Second, the project means a certain action, a set of activities that have a common program, provide targeted actions, organizational form, etc. (publishing project, television project). Third, the project is defined as a completed cycle of productive activities (collective, group, individual, etc.), as a form of building a joint purposeful activity of people" [7]. This understanding of the project, as the researcher notes, led to the separation of certain stages of its development: the design phase, the technological phase (implementation), and the reflective phase (summarizing - evaluating the results, drawing conclusions). Therefore, the author concludes that the essence of the concept of "project" is interpreted in two important aspects: firstly, as a result of the activity the product (productive aspect), and secondly, as an innovative form of joint activities aimed at achieving a certain result (activity aspect) - and defines the category "project" as "a system of implementation of planned successive actions aimed at achieving a certain intended result" [7].

The project method aims at a comprehensive and systematic study of the problem and the development of a specific end product; involves obtaining a practical result, not just a search for certain information. The project is primarily the result of collective efforts of the performers, so at the final stage of activity it involves the reflection on joint work, analysis of its completeness, depth, information support, and creative contribution of each participant.

The method of projects as a method of planning appropriate (purposeful) activities in connection with the solution of educational problems in real life circumstances began to take shape in the late nineteenth century in the US as a "problem method". It was developed in the pedagogical viewpoint and experimental work of John Dewey within the humanity trend in philosophy and education. The term "project method" first appeared in 1908-1910 in the reports of Massachusetts school authorities and was adopted from the agronomic literature. The project method contained the ideas for building learning on an active basis, through appropriate activities of students in relation to personal interests. The project method is based on the concepts of learning through "action" and "free education". J. Dewey's motto was an attempt to help students develop their abilities by collaborating on a particular problem in a collective search and creating a collective project. It was extremely important to show a child their personal interest in gaining knowledge, where and how they may need it in life. The students gained experience and knowledge in the process of planning and implementation of practical tasks which gradually became more difficult during training.

The project method is a genuine product of the American education movement. It was described by William Heard Kilpatrick in his essay "The project method". Professor W.H. Kilpatrick, managed to improve the system of the work on projects, theoretically substantiate the method based on the principle "education is life, not preparation for life"; he offered the first classification of projects (projects created, consumable projects, problem-solving projects, exercise projects). At that time, the project was meant the target act of activity, which was based on a child's interest [11]. Michael Knoll has traced the project method to architectural education in sixteenthcentury Italy and to engineering education in eighteenth-century France. In his articles, Knoll wrote: "Unlike traditional methods, projects focus on the application rather than the transfer of specific knowledge or skills, and more carefully than lectures, demonstrations or recitations, they aim to increase intrinsic motivation, independent thinking, self-esteem and social responsibility".

In Ukrainian education, the relevance of this problem was studied by O. Makarenko as a result of his innovative pedagogical activity, he came to the conclusion about the design of personality as a subject of pedagogical work. This opinion has also been repeatedly claimed by V. Sukhomlynsky whose multifaceted pedagogical heritage is permeated by the idea of human design. The definition of the essence of design as a pedagogical phenomenon is quite complex, because the design system and the pedagogical process itself are extremely complex and valuable. The very word "project" in translation from Latin means "thrown forward, intention, plan" and so on.

In the modern pedagogy, the projects are classified according to a certain dominant typological feature. Following K.S. Polat, researchers distinguish the following projects according to the dominant method or type of activity:

a) applied projects with clearly defined results of the participants' activities (for example, a draft document, a dictionary, a reasoned explanation of any phenomenon, etc.). These projects involve a thorough understanding of the structure, the distribution of functions between the participants, the design of results, their further presentation and external review;

b) research projects aimed at organizing students' activities aimed at solving creative problems with previously unknown results, which involve certain stages of work (reasoning of the relevance of the research topic, subject and object, defining goals and objectives, identifying search methods and sources of information, hypotheses, identifying ways to solve the problem, data collection, analysis and synthesis, discussion and design of the results, presentation of 
communication or report, identification of new problems for further analysis);

c) information projects that are aimed at studying the characteristics of any processes, phenomena and objects, and provide their analysis and generalization of the identified facts. The structure of such a project is similar to the structure of a research one, which is often the basis for their integration;

d) role-playing projects, when the participants perform certain roles (literary or fictional characters) specified by the nature and content of the project; the participants mimic social or business relationships complicated by hypothetical game situations. The structure of these projects is just outlined and remains open until completion [4].

In real practice, the projects of mixed types are mostly used, which combine the features of several types of projects and are practice-oriented. These projects not only allow to gain new knowledge, but also contribute to gaining certain social experience.

An important role at all stages of the activity is given to the teacher who, on the one hand, is the organizer of the project and provides development and training of the students, and on the other, is an equal member of the working group and sets his own goals, analyzes the situation, offers interesting ideas for discussion. The teacher can share their own life experience, help students find diverse sources of information about the research problem, help to contact with specialists, government officials, etc.

The analysis of practical experience of the project activity organization allows to allocate the following main stages: preparatory (semantic and technological aspect), planning of project activity (problem statement, development and planning of certain action), research of the problem and the choice of a way of its solution; activity (problem solving, implementation of the action); presentation of the results; reflective stage (evaluation and analysis of the results).

At the initial (preparatory) stage it is important to motivate students for research work. The stage of preparation for work on the project involves the formation of an initiative group, search or selection of a problem among a number of topical issues, specification of the topic in terms of the reality of implementation, relevance, and social significance. This stage aims at theoretical training of the project participants. It is during this stage the students learn to analyze sources, communicate effectively, and discuss problems with the help of the teacher.

The stage of problem selection and its research involves the analysis of a wide range of problems that need to be solved, and the choice of one of them, which will be the object of study. This stage aims not only at gathering information on the problem of research, studying of sources and accumulation of materials, but also at direct learning and gaining experience of direct activity of the students.

The main task of the stage of choosing the way to solve the problem and develop a plan for its solution is planning made by students on the basis of systematization and analysis of the material given for problem solution. The purpose of this stage is to determine the most optimal solutions of the problem, which are supported by the majority of the group.

The implementation of the problem solution stage involves an attempt to fully or partially realize the proposed action plan of the team, organizing various actions, such as publications in the media; appearance on radio and television; appeals to public organizations; involvement of commercial structures for coworking, etc.

The result of project activities can be any event or specific product: presentation, tour, plan, concert, public speech, book, article, master class, etc. The success of the project largely depends on the design of its results. The presentation of research materials to a wide audience is a necessary prerequisite for working on the project. Successful presentation of research results can give impetus to further problem solution.

Work on a project cannot be considered effective without the students' analysis of the course and results of their activities at different stages of research, i.e. without reflection. At the final stage of project, it is advisable to organize a discussion in which students will be able to assess the project activities as a whole and the personal contribution of each to the common work, to identify shortcomings and discuss ways to overcome them.

\section{Language and communication projects at an economic university}

Language project "Week of Ukrainian Literature and Language." The Department of Business Linguistics of the Kyiv National Economic University named after Vadym Hetman annually implements in November a language project dedicated to the Day of Ukrainian literature and language. During a week, students of various faculties, teachers and university staff actively participate in the events dedicated to the Day of Ukrainian literature and language. There are competitions on essay writing, university dictation, an auction of ceremonial speeches; students present their own advertising video projects "Choose Ukrainian!" There are poetic translation studios. Everyone joins the flash mob "Do not miss the nice words!" The events "Poetic travels \#ЛІРИЧНІЕКОНОМІСТИ" (\#LYRICALECONOMISTS),

“\#ЗАБЕТКОВАНИЙКНЕУ” (\#KNEUALPHAВЕТ), “\#ПІДВІШЕНАКАВА” (\#SUSPENDEDCOFFEE), “\#КНЕУВСЬКИЙДИКТАНТ”

(\#KNEUDICTATION) arouse great interest among the students. The first stage of the all-Ukrainian language and literature competition of Taras Shevchenko and Petro Jacyk is also starting at this time. These events cultivate aesthetic taste, love for the native language, country and people, enrich with new knowledge and approaches in the efforts to improve professionally. In November 2020, the traditional project was implemented online on the Zoom platform.

Language projects of this type contribute to the development of students' sustainable skills of language culture of modern business communication, increase the level of communicative competence of future 
specialists, and form the national language personality of the future economists. The students gain practical experience of language and professional communication due to the language projects of this type and cooperation with teachers of profile departments of international management, international economics, international trade, and economics of enterprises.

Polish language and communication project "Skąd jesteśmy?" ("Where are we from?"). The study of Polish language at the Kyiv National Economic University named after Vadym Hetman started in 2014. Polish projects implemented during the study of this discipline promote the acquisition of communication skills in various areas of professional activity and life. It is advisable to use language etiquette in the situations of real language communication, and to introduce the basic economic terms in Polish.

Ukrainian public organization "Poruch" ("Near") in partnership with the Polish Association "Time Space Identity" and the Department of Business Linguistics of the Kyiv National Economic University named after Vadym Hetman implemented the project "Skąd jesteśmy?" ("Where are we from?"). As part of the project "Where are we from?" through a demonstration of the history of 20 Polish families from Szczecin (Poland), an attempt was made to find the answer to the question: "Where are we from?" To support this idea, Polish producer Adam Kuzycz-Berezowsky and his team have created a film of the same name where the problems of identity, time and space are explored. This film shows people's lives, their thoughts, feelings, experiences, the search for answers to the question: "Skąd jesteśmy?" The video conference before the screening was attended by the co-author of the film, Mr. Antoni Sobolewski, who told about the history of the film "Skąd jesteśmy?", about its shooting and the producer's plans. All this took place in Polish, which allowed future economists to better feel the peculiarities of communication in Polish, enrich their vocabulary and acquaint with the culture of Poland. The students also tried to express their thoughts and impressions from the film "Skąd jesteśmy?" In Polish. This film asks each of us the question. And we already know the answer: "We are from where we are, where our parents are, where our family is, where our country is..." The projects of this type contribute to the improvement of the Polish language culture, the study of the common history of the Polish and Ukrainian peoples, the establishment of international contacts, and form a sense of beauty of future economists.

Language and communication project "Days of Poland at the Kyiv National Economic University named after Vadym Hetman". The Department of Ukrainian language and literature of the Kyiv National Economic University named after Vadym Hetman within the framework of this annual project always plans a lot of interesting and informative events. Competitions for the best essay in Ukrainian or Polish are carried out the students represent their own views on modern relations between Poland and Ukraine, share their vision of the future of both countries. The best essays are published in the Polish newspaper
"Dziennik Kijowski". At the practical classes on the Polish language, students make presentations and video presentations in Ukrainian or Polish about famous Polish writers, economists, public figures, historical figures; cities and villages of Poland, special places or tourist objects, places in Kyiv related to famous Poles or Polish realities, Polish-Ukrainian relations in different historical periods, famous Ukrainians in Poland, etc. Polish films (by Andrzej Wajda, Jerzy Hoffmann, Krzysztof Zanussi, etc.) are shown, followed by writing reviews about them. As part of the celebration of the Days of Poland at the Kyiv National Economic University named after Vadym Hetman, students fulfill a flash mob related to Poland and the Polish language. To acquaint the community of the Kyiv National Economic University named after Vadym Hetman with Polish culture and its prominent representatives, students prepare quotes about famous Polish writers, politicians, economists and public figures. The students give these "Polish flashcards" to their colleagues from different courses, representing the Polish language course in our university. As part of the project, the students take part in the cultural events of the European day of languages in Kyiv, where they attend trial lessons in the Polish language, screenings of European cinema, literary discussions, workshops, competitions, games. The students learn more about Polish cultural centers in Kyiv, get acquainted with Polish book novelties, and actively promote the Kyiv National Economic University named after Vadym Hetman where they study the Polish language. The students are happy to participate in various projects of the Kyiv National Economic University named after Vadym Hetman, related to the Polish language and culture, since they see real prospects for the implementation of the acquired language knowledge in the practice of future professional activity.

Language project "Certification course on modern Polish language business communication". In 2016, the Kyiv National Economic University named after Vadym Hetman offered a new project "Certification course on modern Polish language business communication" for the students studying "International Economics" and "International Business".

The purpose of the certification course "Modern Polish language business communication" is to update the knowledge acquired during the study of the basic course of the Polish language in a specific area of business communication. The program of the course includes: lectures and presentations "Polish language in business communication", a series of seminars "Polish language of modern mass media" (on the example of the experience of Polish language media in Ukraine "Dziennik Kijowski", "Krynica"), language training "Practice of working with Polish-speaking audience" (experience of the Community of Poles in Ukraine), a series of lectures "Polish in the diplomatic sphere" (lectures from the Consular Section of the Embassy of the Republic of Poland in Ukraine), "Polish in tourism" master classes from the managers of the Polish Tourist Organization in Kiev), online lecture "Web-session of questions and answers about the Polish language in 
business" (Mr. Albert Nowacki, Doctor of Philosophy from the John Paul II Catholic University of Lublin, Poland), online lecture "Polish language in science" (representative of the NAS of Ukraine Lesya Lazarenko, Berlin), coaching seminar "Polish language in business" (from representatives of the International Union of Polish Entrepreneurs in Ukraine), etc. Master classes "Fundamentals of translation from Polish into Ukrainian of economic texts", "Fundamentals of translation from Ukrainian into Polish of economic texts" are also planned. At the end of the course, the students prepare presentations of group language cases. The course is completely free, and all students participating in the project receive certificates [14].

After mastering the course, the students gain not only knowledge of modern Polish economic terminology, but also real practical skills of using the Polish language in business, which is an indisputable advantage for further career growth of future economists of European level.

Project "Paths of Trypillian civilization". The Department of Regional Studies and Tourism of the Kyiv National Economic University named after Vadym Hetman implements the project "Paths of Trypillia civilization", among a number of professional disciplines.

Each region in Ukraine at the present stage turns the pages of its history and culture in order to bring them into the category of tourist destinations [8].

The Trypillian civilization is one of the oldest ones in the world. It developed in Ukraine 7000 years ago. The Trypillian culture (it got its name from a settlement near the village of Trypillya in Kyiv region, discovered and studied by archaeologist Vikentiy Khvoyka in the XIX century), its level of development and quality of life impress modern archaeologists [12].

Upon the training of future tourism managers, a student project was created to promote the Trypillian culture. The project has the following goals: resuscitation of the improperly forgotten route through the Trypillian region of Kyiv region, which will promote the development of the tourist business of the region; formation of self-awareness among the youth on the basis of national dignity and respect for their own origins due to the involvement of historical and cultural potential of the Trypillian heritage; acquisition of professional skills in the development of the excursion route by students of the profile specialty "Tourism" upon the implementation of the project stages; conducting field theoretical and practical lectures for the students and teachers on the Trypillian culture.

Participating in the project, the students try to develop a holistic tourism product for different groups of tourists. It consists of two parts, separate and interdependent in terms of organizational activities and venues.

The first tourist offer are excursions for school and student groups "Paths of the Trypillian civilization" on the route "Kyiv-Trypillya-Khalepya-Vytachiv-Novi Bezradychi-Kyiv". The one-day educational and entertainment tour lasts 9 hours. The target audience are tourists of all ages, students, modern youth, who are interested in the historical and cultural heritage of Ukraine, Kyiv region and the Trypillian civilization.

The second tourist offer are field lectures for schoolchildren with master classes on the topic: "The secrets of Trypillia." The plan of this tourist event includes a short presentation of the phenomenon of the Trypillian civilization with video materials prepared by the Kyiv National Economic University named after Vadym Hetman students; acquaintance with the applied culture of Trypillia (the students of the Kyiv National Economic University prepare and conduct master classes in creative groups, where they fabricate pottery with Trypillia symbols, paint linen, wood, paper blanks or clothes with the Trypillian ornaments).

The main activities provided by the project are the following: educative, educational, creativity of youth and schoolchildren in the cultural sphere, educational and productive activities of the students (organizational, excursion, marketing activities, advertising, etc.).

In parallel with the implementation of the project, the teachers conducted classes in the disciplines "Local history", "Geography of tourism", "Tourist country studies", "Fundamentals of excursion activities", "Geography of culture". The students studied the scientific works of famous scientists who investigated the Trypillian civilization: V. Khvoyka, O. Olzhych, M. Videiko, V. Chabanyuk, other historical materials, artifacts of the historical museums of Trypillia, Kyiv, and Vienna. Also during the study of these disciplines, there were master classes and meetings with the folk artist and master of reconstruction of Trypillia ceramics L.I. Smolyakova in her private museum "Dyvosvit Trypillya" [13].

As a result, a scientific conference was held on the topic: "Trypillia the civilization of creators". Among various areas of the event at this conference, our students demonstrated a master class on sculpting the Trypillian souvenirs.

The students specialized in "Tourism" also participated in various thematic events: festivals of the Trypillian culture, cycling and festival "The Trypillyan miracle" organized by the local community of Novoukrainka, master classes on sculpting the Trypillian clay products during thematic events and exhibitions. During the preparation of the excursion route, trainings and visits to the settlements on the route were carried out: Novoukrainka, Trypillya, Khalepya, Vytachiv, the exhibitions of the V. Khvoyka's museum, the regional archeological museum of the Trypillian culture in the village of Trypillya, the settlements of the village of Shcherbanivka and Divych-gora, etc.

The highlight of the proposed route will soon be the center "Renaissance" in the village of Novi Bezradychi, where, among other unsurpassed exhibitions, a pottery workshop and built a Trypillian furnace are created. A separate segment of tourists was also invited to get acquainted with the amazing hotel and restaurant complex "Trypillya Sun" where one can get an interesting mini-tour, see a master class of famous chefs, and try and taste the Trypillian dishes. 
After studying the transport infrastructure of the route, its possibilities and shortcomings were analyzed, and certain recommendations for drivers were developed. The above mentioned objects are included into the developed excursion route of a one-day tour, which was first tested for students of the Department of Marketing of the Kyiv National Economic University named after Vadym Hetman. During the project implementation, the teachers of the department and students took part in the seminar of history teachers "Innovative approaches in teaching the Trypillian topics in school courses of disciplines of secondary schools." There were also field lectures with a demonstration of master classes on the Trypillian topics for the schoolchildren of Kyiv.

The project "Paths of the Trypillian civilization" developed by the students and teachers of the Kyiv National Economic University acts as a means of organizing axiological (value-oriented) space and significantly affects the development of personality by expanding the accessibility of historical and cultural heritage for different target audiences. The creative activity provided by the project gets new qualitative characteristics through the immersion into the life and cultural traditions of Trypillia, and plays an important role in the personal and professional growth of future economists.

The project "Paths of Trypillian civilization" will help and promote the following aspects:

- preserving the integral state of the natural heritage of a region as a tourist resource;

- introducing the innovative methods and practices of language, communication, historical, cultural and educational activities with a focus on a certain age group;

- increasing the efficiency of operation of existing tourist infrastructure facilities, as well as the creation of new jobs directly or indirectly related to the project, in particular: guides, workers of catering establishments, specialists of creative workshops, employees of transport and travel agencies, museums;

- improving the quality of services in order to increase Ukrainian tourist flows to the destination sites and to attract foreign groups to acquaint young people of foreign countries with the historical and cultural heritage of Ukraine;

- supporting the domestic producers of goods and services, due to the involvement in the complex of the project program of processes for the manufacture of related to the theme of the Trypillia souvenirs, confectionery, clothing, toys, accessories, etc.;

- creating the conditions for tourist travel with appropriate excursion content and field lectures with master classes for children and youth with disabilities and for socially vulnerable groups;

- intensification of educational work provided by the relevant programs of secondary schools through excursions, training sessions (on the history of Ukraine, drawing, work, etc.), extracurricular educational activities.

Hlukhiv project. A long-term student project is also the so-called "Hlukhiv project" with a working title "Conceptual approaches to the formation of a holistic tourism product of the Hlukhiv city: a study of the current state, problems and prospects for its development." The purpose of the project is to develop conceptual approaches to creation of an integral tourist product of the Hlukhiv city (Ukraine) on the basis of empirical data.

A number of tasks were set and solved to develop the project:

the tourist potential of the city for creation of a competitive tourist product directly under the expeditions of teachers and students in Hlukhiv was investigated;

the necessity of the popularization of the objects of historical and cultural heritage of Hlukhiv is highlighted;

proposals on the development of tourist infrastructure of the city with cultural, sports and other events that attract the attention of young people;

the need to improve existing and introduce new thematic tours and tourist routes has been indicated;

- the proposals for the formation of a positive image of the city at the national and international levels have been put forward.

Both students' projects were presented at the AllUkrainian competition of the student works in the specialty "Tourism" in Kharkiv.

When teaching courses "Local History", "Tourist Country", "Urbanism and Tourism", the students are also offered the following medium-term projects with demonstration of educational presentations: "Draft business card of the state", "Draft tourist booklet of the country", "Tourist attractiveness of the European, Asian, and American cities", "Prague, Warsaw, Kyiv (or other cities) the similarities and differences of the modern urban development", etc.

The project "Infographics of the European tourist cities." One of the ways to systemize a large amount of tourist and geographical information and to reduce its volume and simplify perception is the infographics. At present, this branch of design has not become widespread in Ukraine. The infographics is a graphic design of information through visual demonstration, aimed at clear presentation of a significant amount of information and enhancing its perception.

It is worth noting that the use of infographics is just starting to gain popularity in the tourism business. That is why the project "Infographics of the European tourist cities" offered to future tourism managers is relevant and timely and creates new opportunities to achieve the goals: the development and promotion of tourism products.

The purpose of creating and using the infographics in the field of tourism is the rapid spreading of information in an innovative way. The generalized information is presented in the form of symbols and icons. A part of the visual image is also a short text that accompanies it. When an image interacts with a text, two components are perceived simultaneously, visually and verbally.

As known, a person receives about $90 \%$ of information through sight, that is, the visual perception of information is more effective, has a greater impact 
on a person and allows to more effectively present the needed information. Also, the visual form of information is much faster because it is perceived 60,000 times faster than text. People remember only $10 \%$ of what they heard, $20 \%$ of what they read, and about $80 \%$ of what they saw or accomplished.

This presentation of information about the city in the course of studying, for example, the discipline "Tourism of urban agglomerations", has the following advantages: an effective focus on the specific elements of the presentation; processing of a large amount of information without significant information overload; obtaining optimal information about the city in the shortest possible time; highlighting comparisons, relationships, dynamics of upgrade or decline of urban infrastructure; minimization of the material and its aesthetics.

Using the infographics in tourism, it is advisable to effectively and concisely provide the specific information about the city: the popularity of a tourist route, possible options for getting from Kyiv to the tourist centers (transports, distances, ticket prices); number of tourists (inbound or outbound); the state of the city's infrastructure; the availability of the subway and other transports, fares; CityCard; the most popular destinations, attractions, museums; tickets, benefits; pricing policy of hotels of different categories; average check in catering establishments of different types; excursion services (buses, walking excursions); advantages and problems of the city; entertainment, leisure, holidays, festivals, shopping, souvenirs, etc.

The information in the form of infographics about the most popular European tourist centers was posted on the student tourist portal and tested on the personal experience of traveling students; it aroused interest not only among the students of the Kyiv National Economic University and individual tourists, but also aroused professional interest of travel companies, as evidenced by their positive feedback.

\section{Conclusions}

Thus, as M.O. Trygubenko points out, on the one hand the business education is a dynamic system of knowledge, practical actions, aspects, methods and psychological and pedagogical technologies, which is constantly evolving and improving; on the other hand, it is an open socio-economic system. that takes into account individual, collective, local, regional, social and national aspects, forms a personality for living in a business environment and an active personality that develops. In a modern economic university, the language and communication projects in business education combine all these aspects, contributing to the practical study of professional disciplines.

The use of language and communication projects in order to humanize the educational process is a promising and multi-vector direction of the modern business education. These projects give the modern Ukrainian economics education certain national and distinctive features, and allow to adopt the experience of world and European educational practice. Specific language and communication projects implemented at the Kyiv National Economic University named after Vadym Hetman increase the professional, linguistic and cultural competencies of future specialists.

\section{References}

1. S. Grabovenska, Competitiveness of territorial markets of tourist services in Ukraine, Lviv, 222 (2017)

2. L. L. Zalizniak, At the origins of the ethnic division of mankind, NDIU, Kyiv, 7-25 (2018)

3. J. Dewey, Experience \& Education, New York, (1938)

4. K.S. Polat, M. Y. Bukharkina, M.V. Moiseeva, A.K. Petrov, New pedagogical and information technologies in the education system, M., 272 (2009)

5. A. Cymbal, Pedagogical design, Kyiv, School World, 128 (2009)

6. M. Videiko, N. Burdo, E. Slesarev, M. Videiko, Excavations near the village. Trypillia, Archaeological research in Ukraine 2018: yearbook, Institute of Archeology of the National Academy of Sciences of Ukraine, Kyiv, 62-65 (2020)

7. M.O. Trygubenko Business education as a social phenomenon of modernity and a factor of entrepreneurial success, Culture of the peoples of the Black Sea region, 205, 125-128 (2011)

8. Yu.Ye. Kirilov, V.G. Granovska, L.O. Aleshchenko, Formation of competitive advantages of subjects of tourist branch, Economics of agro-industrial complex, 5, 45 (2020)

9. A. Cairo, Functional art: introduction to infographics and visualization, Ukrainian Catholic University, Lviv, 17, 349 (2017)

10. G. Gutek, Philosophical, ideological, and theoretical perspectives on education, New York, (2014)

11. W. H. Kilpatrick, The project method, New York, (1929)

12. A. Zborovsky, The discoverer of Trypillia culture, Kyiv, 12, 10 (2013)

13. Z. Egorova, Vikentiy Khvoyka is an outstanding self-taught archaeologist, Voice of Ukraine, Kyiv, 9, (2019)

14. N. K. Misyats, Modeling of interdisciplinary connections in Polish classes languages in higher education, Educational innovative technologies in the process of teaching disciplines, Zhytomyr, 153-157 (2004)

15. M. Knoll, The project method: Its vocational education origin and international development. Journal of Industrial Teacher Education, 34, 59-80 (1997)

16. M. H. Bleeke, The project: From a device for teaching to a principle of curriculum. Diss., University of Wisconsin-Madison (1968) 
17. J. K. Sood, New Directions in Science Teaching, Kohli Publishers, Chandigarh, 146-149 (1989) 